\title{
IRISH STUDIES \\ ROUND THE WORLD - 2011
}

Patricia A. Lynch (ed.)

Copyright (c) 2012 by the authors. This text may be archived and redistributed both in electronic form and in hard copy, provided that the authors and journal are properly cited and no fee is charged for access.

\section{Reflections on Irish Writing in 2011}

by Patricia A. Lynch

New Collected Poems (2011)

by Derek Mahon

Eoin Flannery

Landscapes of Cult and Kingship (2011)

by Roseanne Schot, Conor Newman and Edel Bhreathnach (eds)

Colin Ireland

Colum McCann (2011)

by Eóin Flannery

William A Johnsen

Demented Particulars: The Annotated Murphy (2010)

by C.J. Ackerley

Obscure Locks, Simple Keys The Annotated Watt (2010)

by C.J. Ackerley

Sean Kennedy

Between Two Shores: Idir Dhá Chladach—Writing the Aran Islands 1890-1980 (2011)

by Mairéad Conneely

Declan Kiberd

Ireland's New Religious Movements (2011)

by Olivia Cosgrove, Laurence Cox, Carmen Kuhling and Peter Mulholland (eds)

Eamon Maher 
City of Bohane (2011)

by Kevin Barry

John L. Murphy

Witness Trees (2011)

by Lorna Shaughnessy

Manuela Palacios

Aibítir Aoise : Alphabet of an Age (2011)

by Celia de Fréine

Manuela Palacios

A History of the Irish Novel (2011)

by Derek Hand

Gerry Smyth 


\section{Reflections on Irish Writing in 2011}

Patricia A. Lynch

The year 2011 saw mixed fortunes for Ireland. Financial austerity was imposed by the new Coalition government, which, while it hurt people, caused great hardship, and increased the forced emigration of many of our best and brightest, was approved by the EU. Rumbles of scandals still continued to emerge from sources such as church, banks, and developers.

While the picture has not materially improved, there are streaks of light on the horizon, in the form of new international and work initiatives. For example, while business is weak in many quarters, a number of major industries have extended their plants and employment openings. Several towns such as Drogheda have taken part in vibrant programmes to support and develop local initiatives in matters of business and environment. On the international scale, major events were the visit of the Queen of England, which went a long distance to heal old wounds, and of the US President, who visited the home of his ancestors and translated his message of hope and confidence "Yes, we can" into Gaelic as "Is féidir linn”. Queen Elizabeth too, used a phrase of flawless Gaelic to introduce her speech to the Irish nation. Their visits to a number of significant and historic places in Ireland led to an increased number of tourists to our shores. Irish sportspeople continued to perform exceptionally well for a small country in many fields, especially rugby and golf. Later in the year, a long, sometimes bloody and colourful campaign on the part of seven candidates led to the election of a President of Ireland who is not only a politician, but also a poet, patron of the arts, and an academic, and a leader in many social initiatives. Finally, in December, the winter did not return to the Arctic conditions of the previous two years, but was relatively mild. A good portent, one hopes.
In the matter of literary significance, there was much activity. Every month one could take one's pick of festivals and schools, large and small, all over the country. These included the Cúirt International Literary Festival in Galway, the Theatre Festival in Dublin, Listowel Writers' Week in Kerry, the Bord Gáis Irish Book Awards, and the International IMPAC Dublin Literary awards. There were also festivals in jazz, film, and dance. Ireland once again figured on the Man Booker scene, in the form of Sebastian Barry's On Canaan's Side (2011) in the longlist.

An artistic and cultural project in September, part of the Absolut Fringe festival, seemed to signify the state of play of the country. Fergal McCarthy installed a manmade island in the centre of the river Liffey, the "artery of the city", once pure and now polluted. It was placed opposite the Irish Financial Services Centre, and also a number of ambitious luxury apartments, as signifying the causes of our present problems. On this he installed a palm tree and a hammock, symbols of the thinking which once saw Ireland as a type of unspoiled paradise island on the far west of Europe. His intention to live on the island for a week did not last long! But the symbolism holds true, for it is Utopian thought which can bring about a reversal of the decadent social order, as scholars in this field would suggest (Hegarty 2011: 16).

As we head for 2016, and the centenary of the events which led to Ireland becoming an independent and sovereign nation, it is to be hoped that fresh thought, patriotism, and artistic endeavour will bring Ireland back to full political, fiscal, creative, and spiritual health.

In a year which saw this reviews editor more conversant with the state of the Irish medical profession than with its literary life, I got to 
review personally just a few books. The first of these is the above-mentioned On Canaan's Side Like Barry's previous books, it is gripping though often harrowing, and beautifully told, with elements of surprise deferred. Once again, his protagonist is an old but still beautiful and mentally vigorous woman, and like the heroine of Secret Scripture (2008), her identity has some mystery elements. Lilly Dunne is the youngest member of the family on whom Barry has drawn for several of his previous novels and plays. While her childhood was exceptionally happy, in spite of the death of her mother at her birth, once the light of adulthood dawns on her she has to endure many painful experiences, until she reaches eighty-nine at the end of the book. Forced emigration is her lot as a young woman, escaping for her life due to events beyond her control, and parting from her beloved father and sisters. She has to endure the death of or betrayal by, the two men whom she loved, the necessity to continue fleeing from hidden enemies across the United States for almost all of her life, in ways reminiscent of Roddy Doyle's Henry Smart (Oh Play That Thing 2004), and the destruction by war of her son and grandson. Lilly embodies a whole century of Irish history, having taken unwitting part in the paroxysms which produced the new state, and her son and grandson are similarly destroyed in the cause of the different wars in which the United States had a part. There are many parallels between her grandson Bill and her brother Willie who was killed in World War One, which keeps history both personal and national, alive and consequent. In all of this heartbreak, it is her gift for friendship which gives her joy and saves her at the end. For a woman for whom life was so dramatic, in a novel which has many elements of a crime thriller, the abiding sense at the end of the novel is conversely of warm feminine domesticity created by her and surrounding her. The second book is Roddy Doyle's collection of short stories, Bullfighting (2011). The title is somewhat misleading, in that the protagonist of each story is a working-class Dublin man, undergoing mid-life crisis, and each an anti-hero to boot. There are variations on the theme, for example one man is recovering from a heart attack, his children have left and his relationship with his wife has faded away ("Recuperating”), and another who rediscovers his bond with his elderly parents ("Funerals"). The stories are surprisingly full of pathos, of the man struggling with the futility of life and a sense of failure. They are mostly in the form of internal monologues, in which the reader gets an Updikelike view of suburban Dublin life and scenes. However, these stories have been published previously in other formats, and the overall impression is of repetition. I have read the vast bulk of the Doyle corpus with pleasure over the years, but this was one book which I was glad to put down.

On the other hand, finishing Dermot Healy's novel Long Time, No See (2011) felt like parting with friends. This is a richly-layered book, and repays multiple readings. It is often witty, and poetic especially in the utterances of some of the characters: "Mister Thomas Feeney said that in his hospital bed he had been riding high next the sister of sorrow" (350). There are echoes of other Irish writers such as Friel in the repetition of a series of placenames by the old men, which represent the geography of their lives and emotions; the elegiac notes of McGahern's novel That They May Face the Rising Sun (2001) may have had an influence too, though these are never obvious. It is told from the point of view of school-leaver Philip, also called Mr Psyche. He is a typically monosyllabic teenager in his own reported dialogue, and tells the reader little enough in describing even his nightmares, but what he does do is to describe in minute detail the day-to-day happenings of his extended family, all surnamed Feeney, in a small scenic north-western coastal area. By doing so, a whole community comes to life, and Healy's descriptive powers are such that we can almost draw a map as well as colourful pictures of the few miles encompassed. Here, old and new come together smoothly. The two men of the older generation, his granduncle and the latter's friend, have their roots in an ancient Ireland of beliefs and rituals, his parents are busy working in general construction and nursing respectively, in today's Ireland. Philip finds himself surrounded by people of all nationalities, particularly Eastern European, but also more globally spread. Search-and-Rescue helicopters 
pass regularly overhead, ghost estates and unfinished premises in the local small town are as much a feature on the landscape as the traditional crafts of fishing, farming and small businesses. Power-walkers pass Philip on the coastal roads, and in a throwback to a less distant pass, a group of hippies proves to be a benign influence on the lives of people whom they meet. But all groups come together seamlessly in ritual events such as holding the Stations (Mass said for the people of the locality in a private house), and funerals, where things take place as they have done for centuries.

Philip might seem to hold the limelight due to being not only the protagonist but to the slowly revealed fact that he is recovering from a very traumatic event in his own life. However, the older people to whom he devotes himself quickly come to dominate the imaginative scene. Granduncle Joejoe Feeney and his friend Tom Feeney, also called the Blackbird, are the most vividly alive of all, and the others seem to exist to care for them. A third contemporary of the men, Miss Jilly Adams, is an eighty-nine-year old widow who lives in the Big House in which she was born, but has an old acquaintanceship with the two men. The novel ends with the subsequent deaths of the men, and the finalising of a mauseoleum for Miss Jilly at her home, in which her ashes will be placed beside those of her late husband. "At last, she said" (367) as the building is finished; her satisfaction is linked with her emotional farewell to the two old men as they are buried. From such different backgrounds, with such diverse histories and social status, they are linked not only by childhood acquaintance, but also with the sense that they are each the last of their kind, in an Ireland which has outgrown them.
History underlies this novel in a less obvious and more subtle way than in the Barry novel above. Philip finds an old wall once constructed by the monks who lived on the island out in the bay. As he removes it he observes the farthest levels of time in the form of fossils in the stone. In addition, as he constructs a curved wall to surround a new garden at their cliff-top home, he is very conscious of the craftsman of old:

I could even feel the sense of balance of the man who had built it. He drew the stone from the coral beach by ass and cart to the spot I was taking them from. As he built alongside me, I was taking his work down. As he dropped a stone into place, I lifted it and carried it away. .. I could feel the way he carried himself. ... In his wall I came across chaffs of wheat that were still dry. The bones of coral. White marble. One clay pipe. I was over and back with the barrow, then I began to build. And he came with me. Fit in, stand back, put in a small stone, and follow the twine (128-9).

The poor salt-laden soil is enriched with good topsoil which comes from Miss Jilly's home, Dromod House, which she herself refers to as "good Protestant earth" (321). Old historical differences and ways of life are reconciled in the new life and growth of the garden, where Philip and his mother plant flowers, vegetables and herbs for the coming spring. The regeneration will be Philip's, but he will be strongly rooted in the past, as his granduncle reminds him when he tells him: "I'm leaving you this house, and this world, do you hear that? ... I'm leaving you a quandary" (61). His father has taught him craftsmanship and his mother has inducted him into care of the elderly, but the legacy of the generation of his granduncle could prove to be a mixed blessing.

\section{Works Cited}

Barry, Sebastian. 2011. On Canaan's Side. London: Faber and Faber Limited.

2008. The Secret Scripture. London: Faber.

Doyle, Roddy. 2011. Bullfighting. London: Jonathan Cape.

2004. Oh Play That Thing. London: Jonathan Cape.

Healy, Dermot. 2011. Long Time, No See. London: Faber and Faber Limited. 
Hegarty, Shane. 2011.“A Crusoe on the Liffey: a man amid the murk and mire”. The Irish Times. September 10. P. 16.

McGahern, John. 2001. That They May Face the Rising Sun. London: Faber.

Dr Patricia A. Lynch is a retired faculty member of the University of Limerick's School of Languages, Literature, Culture and Communication, where she lectured in English Studies/Irish Studies. Her research interests include Hiberno-English as used in Irish Literature, Irish folk medicine, Post-Colonial Studies, Stylistics/Literary Linguistics, Utopian Studies and other aspects of Irish literature. She is co-editor of Back to the Present: Forward to the Past, 2 vols, 2006, Amsterdam: Rodopi, and author of a number of articles such as "Hiberno-English in the Plays of Marina Carr", Études Irlandaises, 2006, Autumn, 31.2, 109-124. 
New Collected Poems by Derek Mahon, Gallery Press, Oldcastle, 2011, ISBN: 9781852355128, 391 pp. €20.

\section{Reviewer: Eoin Flannery}

Such has been Derek Mahon's productivity since the publication of his Collected Poems by Gallery Press in 1999, that it is not entirely surprising to see the recent appearance of his New Collected Poems in 2011 under the same imprint. In the last seven years alone, Mahon has published: Harbour Lights (2005); Adaptations (2006); Life on Earth (2008); and An Autumn Wind (2010). And what is remarkable is not simply the quantity of Mahon's new poetry, but, more importantly, the signal quality of much of this later effusion. There remains the stylistic formality of the earlier work, and a concentration on aesthetics; displacement; and politics. Likewise Mahon treats of the diverse topographies through which he has travelled and resided, alerting us, once again, to his ecological vision. Yet, it seems, in these more recent works that there has been a qualitative change in the nature of this ecological vision. Certainly, Mahon employs the deformities and excess of urbanised global capital in this recent poetry, but there are intimations that this later Mahon is confronting environmental history from a more 'green' political standpoint. In a sense, the poetic voice frequently assumes the tones of ecological advocate for the assailed natural world; forcing a reckoning or, at least reflection, on the past, present and future of all 'life on earth'. Ranging from a largely American-based 'ethics of proximity', which values the ecological credentials of place-dwelling and situated, responsible living, to advocates of planetary ecoconsciousness, the geographical nodes of ongoing ecocritical debates are pitched between the intimately local and the macroscopically global.
The ecological concentrations of Mahon's recent collections meditate on the relationships between human and non-human ecologies; on matters of ecological belonging and placelessness, in local and international contexts; as well as probing the ethics of anthropocentric historical narration in terms of geological time and the 'deep' past.

By far the most sustained of Mahon's ecopoetry in Life on Earth is the sequence, 'Homage to Gaia'; in fact, the sequence is one of the most explicit examples of the coincidence of ecoconsciousness and poetry in contemporary Irish writing. While the sequence cannot measure up to either New York Time or Decadence in terms of sheer length, as well as assuming an alternative formal structure, nevertheless, its relative length and protracted treatment of ecological issues recalls those earlier epistolary and reflective meditations on urban, modern life patterns, which are, of course, ecological in their own ways. Yet, as stated above, there are tonal and thematic divergences between the later sequence and its predecessors, though an ecological sensibility conjoins the earlier work and more recent volumes. In entitling the sequence, 'Homage to Gaia', Mahon signals his concern with a specific, and not uncontroversial, school within contemporary climate science.

In both 'Blueprint' and 'World Trade Talks' from An Autumn Wind, Mahon picks up on the potentially restorative ecological agency of the past in the present and towards the future. Juxtaposing the patterns of urban living in New York City, and thereby cursorily re-visiting the cityscape of New York Time, with a less corporatized worldview rooted in the past,

ISSN 1699-311X 
'Blueprint' insists that: 'There was a blueprint from the past/ but scribbled on by guilty pens/ till it was virtually effaced'. The vehemence of the faith in a historical source is joined by a sense that the source itself was/is, in some respect, taboo or clandestine, and is qualitatively different from the etherized scripts of the internet and digital knowledge. Not only is the unspoken source a suggestive alternative to the present of 'Trucks from New Jersey (fruit and veg),/ panting beneath the window ledge [...] Jeep, Dodge and commuter trains [...] [and] the corporate buzzards', but it is cast in morally ambiguous terms - though this seems to be inconsequential given its inevitable supersession or obsolescence in contemporary times. And the supersession of the titular 'blueprint' is described in further ambivalent language; Mahon's placement of the word, 'virtually', means both/either partial but extensive effacement, and that said 'blueprint' has already been effaced through technological means. And the uncertainty here is important, because if the former is favoured, then the 'secrets the ancients understood', referred to at the close of the poem, are resilient and constitute stubborn utopian survivals or potentials from the past in the present. Whereas the latter, clearly, intimates the future has succeeded, and the past has been processed out of any informative relevance. So, given the impulses divined in 'Ithaca', earlier in An Autumn Wind, it appears that Mahon tends towards the former, a point that is only endorsed in 'World Trade Talks'. The latter poem is an uncompromising confrontation with 'the winds/ of double-edged finance [...] the Chicago Boys, the World Bank and the IMF,/ the dirty tricks and genocidal mischief [...] the war machine'. Abstract financial trading, together with the institutions and philosophies that motor and underwrite the dizzying formulae of inequality and exploitation, jostle for space in Mahon's poem with his own pleas for change, and his apostrophized praise for the critic, Naomi Klein. Amidst the dehumanizing intrusions and agenda of the institutional bodies listed above - whose antics Mahon gestures to in striking a partial rhyme with 'IMF' and 'mischief' - 'World Trade Talks' urges for the consideration and imagination of other ways of living in and thinking about the world and its future. By way of contrast to the rhetorics of violence and manipulation, which attach themselves to capitalist and militarist technocracies, in each of the four stanzas Mahon registers a note of hope or resistance. From the first stanza we hear him ask: 'organic crops/ and comely maidens, is it too late/ to push for these demands/ and pious hopes?' Mahon's irreverent nod to DeValera's prescriptive social imaginary does not invalidate the serious political intent of the query, or defuse the hope contained therein. In the middle two stanzas, he employs 'fight back' and 'survives', suggesting subversion and endurance, and, in particular, the notion of survival is consistent with the thematic and political keynotes of the poems discussed thus far. And survival is the dominant feature of the concluding stanza in 'World Trade Talks', as the poet envisions the future through a constructive use of the past. Coming full circle from the opening stanza: 'Next spring, when a new crop begins to grow,/ let it not be genetically modified/ but such as the ancients sowed/ in the old days'. Again there is an explicit allusion to the guiding wisdom of the 'ancients', of the past; Mahon conveys the idea that tradition is a viable imaginative agent in the present, and is not an obstacle to ecological and political awareness.

With the addition of new poems, as well as the more explicit ecological orientation outlined in the poems above, New Collected Poems also sees Mahon dispense with earlier poems such as: 'The Forger'; 'The Apotheosis of Tins'; and 'A Kensington Notebook' from his self-selected personal canon. The erasure of 'The Apotheosis of Tins' does appear incongruous, considering its direct thematic and political relevance to the renewed ecological attentiveness of his newer work. Besides these deletions, Mahon has also chosen to re-title a number of individual poems and longer sequences. So we note: 'De Quincey in Later Life' (1999) and 'De Quincey at Grasmere' (2011); 'Thinking of Inis Oirr in Cambridge, Mass.' (1999) and 'Inis Oirr' (2011); and 'Morning Radio' (1999) and 'Radio Days' (2011). Of more significance are the substitutions in longer works, where 'New York Time' replaces 'The Hudson Letter'; ‘The Yellow 
Book' gives way to 'Decadence'; and 'The Yaddo Letter' becomes 'Yaddo, or A Month in the Country'. Whatever about the titular changes to the shorter poems above, these changes to longer poems really do not add any value to the titles they have replaced. The fin-de-siècle resonances of 'The Yellow Book' are sorely missed, while the epistolary subjectivity of the other two works are jettisoned to little improved effect. Nevertheless, New Collected Poems is a substantial volume, a testament to a singular voice in modern Irish poetry. Mahon is a poet of conscience, of irony, of the local and the cosmopolitan, and is a writer characterised by an exemplary humanism, as well as an advanced ecological vision.
Eóin Flannery is Senior Lecturer in Contemporary Literature in the Department of English and Modern Languages at Oxford Brookes University, UK. He is the author of three books: Colum McCann and the Aesthetics of Redemption (2011); Ireland and Postcolonial Studies: Theory, Discourse, Utopia (2009); Versions of Ireland: Empire, Modernity and Resistance in Irish Culture (2006). And he is the editor of three volumes: This Side of Brightness: Essays on the Fiction of Colum McCann (2012); Ireland in Focus: Film, Photography and Popular Culture (2009); and Enemies of Empire: New Perspectives on Imperialism, Literature and Historiography (2007). 
Landscapes of Cult and Kingship edited by Roseanne Schot, Conor Newman and Edel Bhreathnach Four Courts Press, Dublin, 2011

ISBN: 978-1-84682-219-3 hbk

xviii +322 pp. $€ 50$

\section{Reviewer: Colin Ireland}

This interdisciplinary volume derives from papers presented at a conference held at NUI Galway on 12-14 June 2009 which had the selfexplanatory title 'Landscape of cult and kingship: archaeology and text'. Literature produced in Ireland from all ages, whether in Irish, Latin or English, has always been known for its strong sense of place. In fact, throughout the medieval period an important literary genre has always been dindshenchas 'place lore'. A large purpose of this conference, and hence of this volume, is to highlight the importance of place from pre-historic through early modern times. The potential time span in these discussions is immense, stretching from c.4000BC to works written after 1800AD (p.xii). This volume achieves its goal by examining the archaeological evidence from diverse sites, typically those having to do with kingship, throughout Ireland and comparing, where possible, what texts of various ages have to say about these easily identifiable places on the Irish landscape.

Among the obvious results that emerge from this approach is the need to identify a continuum from ancient pre-history well into the recent historical past at these various geographical sites. That continuum stretches from a pagan past that cannot be accurately reconstructed through to a historical past recorded in texts created through literacy introduced with Christianity. So, for example, sites that from written texts we know to have been important sites for royal inaugurations, commercial fairs and other social gatherings crucial to the maintenance of social fabric, can also be shown to have profound significance deep in the archaeological records for centuries, and sometimes for millennia, before the sites are recorded in the written texts.

While the continuum of these sites is obvious from examinations of the archaeological records and textual evidence - over at least a millennium in the case of written records - this continuum cannot be confused with a cultural continuity from the pre-historic, pagan period into the literate, Christian era. The archaeological evidence frequently makes clear the shift in the nature of the sacrality afforded a site during the different phases of its existence. So, for example, a site that began in the pre-historic archaeological record as a burial site or cemetery on a promontory, may continue to have a function in the historical period as a place for the inauguration of local chieftains. When one remembers that early Irish texts depict a royal inauguration as a marriage or coupling (banais) of the king with his feminine kingdom, a major aspect of this sense of place in Irish culture becomes obvious. The sacrality of the inauguration site may have continued from the pre-historic period, but the function has shifted in the historical period.

For readers of Estudios Irlandeses the essays dealing with Irish texts will almost certainly have a more immediate interest than those dealing with archaeology. Several of the contributions explicitly combine textual and archaeological evidence. But it is through the archaeological record that we best indentify the continuum of these important 'places' on the Irish landscape.

The first essay by Marion Deane, 'From sacred marriage to clientship: a mythical account of the 
establishment of kingship as an institution', uses the Old Irish text Compert Con Chulainn 'The birth-tale of Cú Chulainn' to show how the narrative trajectory of some early Irish tales must be read at various levels and that certain passages are multivalent. A passage superficially about the marriage of a couple may be read at another level as guaranteeing the fertility of the land, and the relationships between these characters can be read as a marriage or as a form of clientship. Such a close reading of a polysemic text deepens our appreciation for early Irish narrative and its relationship to the landscape. Conor Newman in 'The sacral landscape of Tara: a preliminary exploration' relies on an archaeological approach to show the richness and concentration of remains in the area around Tara and argues that the entire local landscape was loaded with significance. Muireann Ní Bhrolcháin in 'Death-tales of the early kings of Tara' shows the significance of place-names on the landscape with relation to the kings of Tara and where they met their ends. Some of these kings are mythological, others legendary (i.e. semihistorical), and still others (e.g. Muirchertach mac Erca, died c.536) fall within the period of historical records.

In her essay 'Supernatural arts, the landscape and kingship in early Irish texts' Bridgette Slavin asks the question 'what is the connection between the supernatural arts and sovereignty in early Irish texts? (p.66)'. She uses both literary and hagiographical texts to examine instances of supernatural arts exercised by poets, druids and others to shape and alter the perception of the landscape. Roseanne Schot in 'From cult centre to royal centre: monuments, myths and other revelations at Uisneach' examines the ceremonial and sacral centre Uisneach, 'the navel of Ireland' in modern Co. Westmeath, by examining both the archaeological record and written texts, and displays both the literary and archaeological wealth of the site. Marie Lecomte-Tilouine's essay 'Imperial snake and eternal fires: mythified power in a Himalayan sacred site of royalty (Dullu, Nepal)' is included as a comparative study showing that clear parallels are found in other far-flung parts of the world.

Edel Bhreathnach's informative and wide- ranging essay 'Transforming kingship and cult: the provincial ceremonial capitals in early medieval Ireland' examines 'what happened at Tara, Tailtiu, Cashel, Cruachain, Emain, Uisneach, Tlachtga, Dún Ailinne and Carman between AD600 and 1200 (p.126-7)'. Simply listing these major ceremonial sites is a clear reminder of the cultural depth to be found in the landscape and dindshenchas of Ireland. Bhreathnach concludes by stating that her essay 'offers the initial steps towards an understanding as to how changes in early medieval Irish society and institutions influenced the use and physical development of the royal provincial capitals of Ireland (p.148)'. Brian Lacy in 'Three "royal sites” in Co. Donegal' examines the Gríanán of Aileach, Tullaghabegley, and Croaghan Hill, all local royal sites within the county of Donegal, and reminds us that these local sites existed and functioned much as did the larger regional royal sites of Tara, Rathcroghan (Cruachain) or Knockaulin (Dún Ailinne). The cooperative effort by several people from several institutions is a good reflection of the interdisciplinary thrust of this volume of essays. Elizabeth FitzPatrick, Eileen Murphy, Ronan McHugh, Colm Donnelly \& Claire Foley joined forces to produce 'Evoking the white mare: the cult landscape of Sgiath Gabhra and its medieval perception in Gaelic Fir Mhanach', a study that relies on archaeology and textual analysis to show the sacral significance of some local sites in Co. Fermanagh that are, of course, paralleled at the major regional sites elsewhere in Ireland.

John Waddell in 'Continuity, cult and contest' emphasizes the notion of a continuum in usage at various ceremonial sites, concentrating specifically on Tailtiu (Teltown), Co. Meath, and Cruachain (Rathcroghan), Co. Roscommon. Ger Dowling's 'The architecture of power: an exploration of the origins of closely spaced multivallate monuments in Ireland' is an inquiry into the purpose and function of the closely spaced ditches and ramparts that encircle many sacral sites associated with burial and ritual in Ireland. Kay Muhr works for the Northern Ireland Place-name Project and her contribution 'Place-names and the understanding of monuments' comes closest to any of the other essays in this volume to being a modern example of dindshenchas ‘place lore’ itself. Her study 
limits itself to sites found in Northern Ireland and relies on a wide variety of sources to explain the names of the sites. Ann Dooley in 'The inauguration ode?' examines bardic poems of minor families from the late medieval period to address the question in the title. Among her conclusions is the argument that some of these poems were as much a prediction of future status as a confirmation of that status.

This volume makes an important contribution to our understanding of Irish cultural history and how the land of Ireland itself blends with and is represented in the rich literary heritage.

Several of the contributions are well illustrated with photographs and helpful maps, and the colour plates at the centre of the volume add to the visual appreciation of these disparate sites and their cultural history. There is good crossreferencing from article to article within the volume and the bibliography at the back of the book is inclusive of all references used from all the articles. The indices at the back of the book are very helpful to anyone researching these rich aspects of Ireland's cultural history with a placename index, a personal-name and collectivename index, and an index of sources. The editors deserve our gratitude for their efforts in bringing this interesting interdisciplinary volume together.

Colin Ireland recently retired as resident director for Arcadia University's College of Global Studies in Ireland. He is the author of Old Irish Wisdom Attributed to Aldfrith of Northumbria: An Edition of Bríathra Flainn Fhína maic Ossu (1999). He co-edited with Maria Tymoczko a volume of essays for the ACIS entitled Language and Tradition in Ireland: Continuities and Displacements (2003) as well as a special volume of Éire-Ireland 38/12 (Spring/Summer 2003). 
Colum McCann, by Eóin Flannery

Dublin: Irish Academic Press, 2011

ISBN: 9780716530497 (cloth)

ISBN: 9780716530503 (paper)

Reviewer: William A Johnsen

Eóin Flannery has written a strong book on Colum McCann, working his way from a fulldress justification for a single author study, through McCann's entire output, in the order in which it was published. Flannery insists (and he is very insistent) on seeing in McCann's writing a redemption for his characters, a utopian motive unfolding across his work.

Flannery is thorough and up-to-date. He coordinates his reading of McCann with all the relevant primary and secondary material (usefully catalogued at the end of the book); his references to other writings on McCann in general (with the perhaps understandable exception of John Cusatis's book Understanding Colum McCann, University of South Carolina Press, 2010) are right up to the moment, and his ideas of utopia are integral with new voices, other emerging scholars. I like that. On the new model, Utopia is not a well-constructed other world necessary because this world is not assailable, impregnable, lost to us in our lifetime; utopia can be seen in hope for a better world not so far away, recoverable through rites of redemption. Flannery's emphasis on the redemptive is strong, even inexorable.

Flannery taps McCann's website collection of interviews and other websites to carefully convey the rhetoric which McCann shares with many contemporary writers, the responsibility to give voice to the voiceless. McCann's formula, slightly different, no doubt because he is restive with the patness of the formula, is that he talks "with" these liminal characters, not for them. Of course it is not that simple, even on McCann's improvement; writers conjure the audience these voices can never win for themselves, they draw listeners otherwise disinclined to hear.

The first chapter "Arrival and Departure" on McCann's short story collection Fishing the Sloe-Black River (1993) nicely sets it in the context of other contemporaneous early 1990s publications such as Dermot Bolger's anthology Ireland in Exile, but also The Irish Diaspora Project, retuning our ears to the specific historical resonances of emigration, globalisation, postcoloniality near the end of the last century. Flannery detaches McCann from Bolger's custody by insisting that McCann is not an émigré who resents his country, thus lumbering the reader unnecessarily with a mistaken idea about Bolger, (the lifelong resident of Finglas), and divesting McCann as well of Bolger's sturdy 1993 defense of Irish writing against the term postcolonial literature as a "decomposing chicken in search of its head."

Flannery invokes Joyce's Dubliners to model the community that can be indicated even by stories of characters who feel alone. When they are gathered together in a short story collection, we read (or redeem, in one of Flannery's persistent terms) that community across the stories, across the heads of these characters

Flannery pays extended attention to McCann's first story "Sisters" which begins "I have come to think of our lives as the colours of that place-hers a piece of bog cotton, mine as black as the water found when men slash too deep in the soil with a shovel." Flannery says this language "overtly" invokes Heaney's volume North (1975). Does it? "Overt” may be too strong but this is an engaging idea to consider, 
Sheona and Brigid as bog queen sisters, an example of Flannery's strength as a reader and critic. When Flannery says that the story "Stolen Child" echoes Yeats, he has the authority of McCann's copyright credits, but Brooklyn as a setting does not necessarily invoke (without any referential or stylistic nudge from McCann) Whitman any more than Hart Crane (or Woody Allen or Duke Snyder) to triangulate Yeats as Flannery also insists. And when he says that the title "Sisters" "is a precise literary historical intertextual allusion to the first story of Joyce's Dubliners" (26), I can't see anything in Joyce's story to connect to McCann's. Flannery's strength is sometimes his weakness.

Each chapter insists on the constant theme of redemption, utopian hope for those who live in liminal spaces, but each chapter is set in a different theoretical ground. Flannery's chapter on Songdogs (1995) widens out to work up as context to Moretti's idea of the European Bildungsroman, in fact a double take, as Flannery suggests, since we get the growth of the father as well as the son. When Flannery lets his prose stand too close to McCann's, we see ourselves:

McCann's panoramic description accentuates the defamiliarising physicality of the transitional experience, as Conor traverses the nocturnal Mexican desert-scape aboard a bus that 'rattles along in darkness, through desert and small towns on the edge of spectacular canyons, and into vast city suburbs" (78).

As critics we must sometimes face up to literature's superior swerving immediacy; if we have to write "defamilarising" and "traversing" to urge a reader to keep up with McCann's more attractive prose, so be it. We serve as best we can. Occasionally Flannery, perhaps in envy, cracks out a rare verb, using "flense" and "brachiating" twice each.

Because he follows McCann's interests, Flannery discusses emigration, the Troubles in the North, Roma culture, and 9/11, but (for a single author study) we get a surprisingly full ensemble of critical theory in this book as well: orality, the body, Ernst Bloch on hope, Victor Turner on liminality, Theodor Adorno on music, interesting and usefully referenced reflections on dance and photography theory and performance.
Dancer (2003) which Flannery identifies as McCann's "most sustained interrogation of the interior workings of memory, historical record and literary representation" (134) to date, is a powerful test case for Flannery and Flannery's McCann. In his chapter "Representation and Performance," Flannery surveys the postmodern case against historical and especially biographical narrative. Marshalling Linda Hutcheons' The Politics of Postmodernism (1989) and Richard Jenkins' Refiguring History: New Thoughts on an Old Discipline (2003) (although he censures Jenkins' "feverish deployment of theoretical rhetoric") Flannery insists on McCann's subscription to the postmodern unreliability of narrative position.

Postmodernism creaks in Flannery's usage: Flannery commiserates with McCann's task before "the disabling distance of time and place in approaching those past personalities, places and events." (139) What narrative ability allowable by postmodernism is disabled by distance and time, or enabled by proximity?

In Dancer, Rudi writes to his sister to explain why he did not cancel his performance in Italy after hearing of his father's death. Rudi writes resolutely that dance is everything to him, sorrow as well as joy: "So I danced him alive." Here is how Flannery sees it:

The past, his father, their life together are resurrected through Rudi's balletic dance, through his body's dynamic and transcendent performance, which obliterates the staid uniformity of linear history. The dancing body, and Rudi's life, interrogate the boundaries of both historical time and historical narration (151).

Postmodernism wore itself out romantically interrogating, puncturing the certainty of others. Doubt is "wounding doubt" (Joyce's Richard Rowan) only at the initial loss of certainty. In the end, one doesn't know for certain whether one knows or not (maybe one does know), one doesn't know whether it has always been (knowing or unknowing), or will always be this way. That's it.

Flannery's own "high-temperatured prose" is inspired by the emphatic quality of McCann's prose which makes it attractive, even compelling to think that Rudi in some way defiantly dances against his father's death. Flannery is trying to 
respond to, to match McCann's intensity, the drive behind his prose. McCann's emphasis must mean more than just resonant description. Here is the critic's most dangerous liability, swayed by the passion of novelistic description to find an equally emphatic significance: are all repeated behaviors in McCann (such as fishing) inevitably rituals or even ritualistic, are all hopes utopian, are all recoveries or provisional improvements in a human life redemptions, even in fiction?

One of McCann's most remarkable gestures is to begin Dancer with a horrific five pages of description of what Russian soldiers suffered from elements and armaments in the war. Flannery helps us see McCann showing us that Rudi's extreme physicality, the way his performance at once obeys and disobeys the rules, originates, comes out of such terrain. When the young Rudi dances for the surviving soldiers,

The dance troupe represents the endurance of art, but equally the contrary actuation of the body in history as a site of redemption and as an instrument of aesthetic beauty. In this anonymous sight of Rudi the boy-performer, we begin to appreciate the affective agency that Rudi will wield over so many in the ensuing years of his career. At this juncture, however, the dystopian terrains that assail the bodies of the Russian soldiers, that dismember them as sacrifices to politics, are countered by the utopian energies of Rudi's boyish grace in dance (155).

I sympathise with Flannery's hope, but you must pay for hope to give hope weight. I cannot believe in the equality Flannery gives to dance against the horror of battle, against the death of the father. Only in a weightless postmodern equation (or in a truly religious dimension) can they be counter, can dance (or narrative) redeem war and death.

William A Johnsen is Professor of English at Michigan State University. He is the author of Violence and Modernism. Ibsen, Joyce, and Woolf (2003) as well as many articles in the area of modern British, Irish, European literature and critical theory. Professor Johnsen is the Editor of Contagion, the journal of the Colloquium on Violence and Religion, as well as two book series at Michigan State University Press. 
Demented Particulars: The Annotated Murphy by C.J. Ackerley

Edinburgh: Edinburgh University Press, 2010

ISBN9780748641505.

259pp.

Obscure Locks, Simple Keys The Annotated Watt by C.J. Ackerley

Edinburgh: Edinburgh University Press, 2010

ISBN 9780748641512.

295pp. Price: £19.99.

Reviewer: Sean Kennedy

With the publication of his recent Samuel Beckett and Science, C.J. Ackerley has confirmed his status as one of the world's foremost critics of Beckett's work. The fruit of long years of painstaking research, Ackerley's work has begun to synthesise his vast array of knowledge into new and compelling readings of Beckett's signature works, and the results are exhilarating. His recent essay-length contribution to the Blackwell Companion to Samuel Beckett, on the same subject, was stunning, and reveals a critic working at the height of his powers. Ackerley has fallen into a habit of producing indispensable books, as is the case with his recent Faber Companion to Samuel Beckett, with S. E. Gontarski, and so it is particularly fitting that two earlier works, The Annotated Murphy and The Annotated Watt, should be re-published. This is where it all started, and where scholars got their first real taste of what Ackerley was capable of. When Gontarski suggests, in his new preface to The Annotated Murphy, that this book "will form the starting point of all Murphy and much Beckett scholarship well into the twenty-first century" he is stating what everyone in the field knows all too well. To read either Murphy or Watt now without these companions is almost unthinkable. There is, simply, too much indispensable information here.

Reading early Beckett can be daunting. He was a note-snatcher and a writer of abstruse pastiche, where any given sentence might be lifted from Saint Augustine, Spinoza, a book about Chinese music or a nineteenth-century treatise on masturbation. Beckett's reading was as wild and wonderful as the prose he produced by way of it, and scholars like John Pilling, who have been painfully editing the archival notebooks in which much of this reading was recorded, have done a major service to Beckett studies in making that reading available to the wider world. In turn, scholars like Ackerley have built on those Herculean labours with Herculean labours of their own. Anyone approaching Murphy, but in particular anyone seeking to write about or teach the book, will want Ackerley's text beside them. The introduction to the Murphy's Mind section, to take just one example, provides students with a clear sense of just what is at stake in Beckett's work: that his obscurity is not gratuitous however it might seem, at times, obnoxious to their somewhat bewildered sensibility. Open The Annotated Murphy at any page and you will learn something, e.g. "Grave’s Disease: exophthalmic goitre, a thyroid disorder occurring mostly in women, and characterized by bulging eyes, fatigue and emotional irritability. It was identified (1843) and named after Dr. Robert Graves, physician to the Meath Hospital in Dublin” (64). And so it goes.

Similarly, the Annotated Watt. Many still

ISSN 1699-311X 
persist in designating Watt a mad work, an unhinged offshoot of Beckett's wartime ennui, but Ackerley's annotations reveal, time and time again, the philosophical rigour with which Beckett approaches the demented Big House of Mr. Knott and Watt's travails within it. Ackerley is an expert on the novel, but also the incredible Watt notebooks, housed at the Harry Ransom Center in Austin, Texas, which are as difficult to read as they are to account for. Ackerley excels at both. He frequently expands on details in the novel by way of an account of the contents of the notebooks, much of which were excised in the move towards a final draft. If for example, you are wondering what are the "foods of various kinds" that Knott has in his stew, Ackerley faithfully transcribes a list of ingredients, which includes " 1 large tin asparagus soup, * hot; $1 \mathrm{lb}$. potatoes, boiled, mashed, with skins, hot" and so on. There is, simply, no way to describe in a review of this length quite how much detail, much of it as demented as the novel itself, that Ackerley has been able to command in his collation of sources for Beckett's most mischievous novel.

One of the most exasperating, and entertaining, aspects of Watt is, of course, the ever-proliferating series of permutations, which exhibit disdain for the reader and invite him or her to quietly get lost. Ackerley refuses to do so, and his annotations offer helpful tabulations of each, so that the reader can begin to get their head around details many find simply overwhelming. Where "twelve possibilities occurred to Watt," Ackerley charts and describes them. Indeed, Ackerley frequently corrects or extends Beckett's calculations, where Beckett's own fatigue and disgust let him down (108-9). Ackerley is also the best person to go to for an explanation of the notorious "Addenda" to Watt that have exercised scholars since the book first appeared. Moreover, the Addenda to Ackerley's own book are astonishing, including a list of the major errata across all editions, tabulated and explained, as well as a brief history of the evolution of the book, further explaining the role of the notebooks. This kind of scholarship is exemplary, painstaking and, occasionally, painful to contemplate, and we are eternally in Ackerley's debt for doing this work, and doing it so well.

In his updated preface to the works, Ackerley acknowledges many of the changes that have been made for this new edition, including the incorporation of recent scholarship and the toning down of a "few overly-enthusiastic comments" (5). There is an acknowledgement here that Ackerley is, on occasion, prone to certain excesses of style, not all of which work in his favour, but this is a small price to pay for the opportunity to avail of his extraordinary knowledge. A more serious problem, at least for scholars interested in Beckett and Ireland, is the somewhat cavalier manner in which that scholarly work is dismissed in both books. Ackerley felt, in 2004, that "attempts to reclaim Beckett for the Irish, from Harrington to Cronin, have proved unconvincing" (11), and that judgment stands unamended in this second edition. Ackerley's use of the term 'reclaim' frames such work as a wrong-minded expression of some prior claim to Beckett on behalf of such scholars, and this seems, to me, unfair.

Moreover, it is a prejudice that results in oversights in the work itself. To take just one example, from The Annotated Watt, Ackerley provides a long list of works "relevant" to Watt. This includes, to give some sense of the extent of it, works on Beckett and mathematics that appeared in scholarly journals in Argentina, as well as minor articles on Mercier and Camier (where Watt appears briefly as a character) which have precious little to say about the book. However, the main works on Watt in the Irish tradition are ignored. Neither John Harrington's The Irish Beckett nor Ellen Wollf's (1994) Journal of Beckett Studies article on Watt appear in this list, not to mention other short pieces by Julie Campbell and Julian Moynahan. This might be construed as an incidental omission, were it not for the extraordinary care taken in other aspects of the work. The comment from The Annotated Murphy proves that Ackerley was aware of Harrington's work, for example, and we can only conclude that, for Ackerley, Irish scholarship is not relevant and does not deserve a hearing. This is a shame, but given that he has characterized work on Beckett and Ireland in his preface to the Faber Companion to Samuel 
Beckett as a 'recolonisation' of one of modernism's 'consummate European[s]' it is, perhaps, not surprising. Inevitably, this leads to blind spots in the annotation process, too, so that Beckett's use of William Carleton in the notebooks, for example, is not noted here. This means that while scholars of Beckett and philosophy may be more than satisfied with this new edition, scholars interested in Beckett and Ireland will still have to travel to Austin to consult the notebooks themselves. The possibility of a synthesis of both perspectives, which is where we might want to be going, is certainly helped along by these extraordinary books, but the relevance of Ireland will have to be established without Ackerley's help.

Sean Kennedy is Associate Professor of English and Coordinator of Irish Studies at Saint Mary's University, Halifax, Nova Scotia. He is currently editing a collection on Beckett and Politics. 
Between Two Shores: Idir Dhá Chladach — Writing the Aran Islands 1890-1980 by Mairéad Conneely. Peter Lang 2011.

289pp.

\section{Reviewer: Declan Kiberd}

The Aran Islands have often functioned as an open, even utopian, space in which outsiders could read the lineaments of their own desires. The playwright J.M. Synge, newly arrived in 1898 from a sojourn in Paris, saw them as a sort of socialist commune. Even today some idealists hope to find in them a version of an eco-friendly counter-culture and one is reported in this book as returning in disgust to the mainland after sighting a branch of Supermacs on Inis Mór. But the romanticizing impulse, as Mairéad Conneely shows in this engaging and wide-ranging study, can be found also among some islanders themselves and especially among those like the poet Máirtín Ó Direáin who have had to leave. Working for most of his life as a civil servant in Dublin, Ó Direáin spent so many years away from the islands that he had time to find in them a past Ireland which offered 'faoiseamh'(relief), 'coinnle geala' (bright candles) and a people who spent their days 'ag labhairt filíochta i ngan fhios dóibh féin' (speaking poetry unknown to themselves).

That idealization, at least in the case of Ó Direáin, was accompanied by a ferocious critique of city life, a life characterized by images of loose women, hollow men and general cynicism - a potent blend of Eliotic ennui, deskman's torpor and Celtic revivalist ideology. Yet there were times when the poet presented a more inflected version of himself, as of someone who had no final home in which to hang his hat:

Idir dhá chladach $\backslash$ Atáid na héisc uaim,\Idir dhá cheacht $\backslash$ Mo dheis a chaill.

Between two shores $\backslash$ Are the fish I seek, $\backslash$ Between two traditions $\backslash$ I have missed my chance.
Dr Conneely takes her title from this poem but, far from seeing the in-between condition as a deprivation, she argues that it represents an imaginative opportunity, linking the otherwise disparate writings of Emily Lawless, J.M. Synge, Liam Ó Flaithearta and Máirtín Ó Direáin on the islands as theme.

Her presentation of Lawless's Grania is an act of critical rehabilitation, for she sees the author as someone who moved well beyond either a unionist or nationalist position and who could accordingly present her protagonist as simultaneously both inside and outside the community. The subtleties of such a stance did not protect her against that depression and mental turmoil which was part of her aristocratic family's inheritance, but Dr Conneely defends her in the face of neglect by nationalists of a later period and of a critique by Synge, who considered her insufficiently familiar with island life. Synge thought her ill-advised to use the novel as a form to render island life, yet he himself spliced some elements of novelistic narration with those of the fragmented modernist travelogue to produce The Aran Islands.

Dr Conneely, in due turn, defends Synge against those critics (including his greatest admirers) who find that book jagged and inartistic. She reads it as a kind of spiritual autobiography and the islands as a zone which offered Synge, in objective splendour all around him, a version of that inner life with which he had struggled but failed to express for most of the previous decade. What he shared with Lawless, of course, was an old ascendancy desire to avoid the accusations of history against his

ISSN 1699-311X 
own people and a felt need to impatriate himself through geography, landscape and the terrain. But Dr Conneely also registers the honesty and humility of his main motivation: to get to know the people by living among them. What Synge discovered was that, no matter how deeply he mastered Irish, he would always feel an 'interloper': yet this is precisely the same feeling of estrangement which would later assail that native islander, Ó Direáin, whose poetry over the passing years recorded how his very artistry had left him an inner exile, even in the days of his childhood. Hence his fellow-feeling, voiced in 'Ómós do John Millington Synge' - as if both of them, in recording the flowering and loss of a culture, were doomed to record its memories ' $\mathrm{i}$ dteanga eachtrann'(in an alien tongue).

In reviewing her authors and the realities of island life, Dr Conneely is careful to restore a sense of the material history which has too often been overlooked or deflected by simplifiers. Inter alia, she reminds us that Ó Flaithearta's generation had better written and practical English than Irish on leaving school. She also reports that Inis Mór had long been anglicised and that there was even sympathy among some islanders for the Black-and-Tans. She helps readers to understand the contrarian impulses that led Ó Flaithearta to join the British army during World War One and then to support the republican insurgency during the Civil War in Ireland. Caught between writing in Irish and English, he represents the 'in-between' state even more comprehensively than the other authors: Dr Conneely shows that the failure of the Gaelic Drama League to pay him a promised fee for his Irish-language play Dorchadas left a psychic wound which goes some way to explaining his resort to English after the commercial success of The Informer. She repeatedly regrets the lack of a proper biography of this fascinating man, whose Dúil constitutes one of the great collections of short stories by an author in either Irish or English during the past century: but the reasons for this may have less to do with his oscillations between languages than with the paucity of documentary evidence which he left and the unreliability of what little there is.

The islands are and were a place apart. Breandán Ó hEithir, Ó Flaithearta’s nephew, was once described as 'Árannach a tháinig go hÉirinn' (an Araner who came to Ireland); and when the young Muiris Ó Súilleabháin stepped on to the quayside at Dingle he was asked 'An Éireannach thú?' (Are you an Irish person?), to which he replied 'Ní hea - ach Blascaodach' (No - a Blasket person). Even the mainland Gaeltacht is a mere effect of colonialism as well as a reply to it but in no ultimate sense a transcendence of such forces. The Gaeltacht is in the end a native quarter, with all the potential and limits which that phrase implies. But the islands seem something else again - too detached to be decodable in terms of any single official discourse.

This may be what Dr Conneely means by 'islandness'. Her study recapitulates and tests many of the set themes of Irish Studies postcolonial, feminist, utopian theories - against the stubborn, unyielding realities of island life. In the last analysis it finds some, but no final, truth in each approach. This work began as a thesis; yet, like Synge's beautiful account, it is an exercise in Negative Capability - prismatic in its openness to many interpretations, unwilling to stabilize any one, honest in reporting the ways in which the subject eludes an ultimate formulation. And, as in The Aran Islands, this study towards its end becomes ever more fragmented, as if such a work (like the islands themselves) can be abandoned but never quite finished.

Declan Kiberd is Donald and Marilyn Keough Professor of Irish Studies at University of Notre Dame. He lectured for more than three decades in Anglo-Irish Literature at UCD. Among his books are Synge and the Irish Language (1979), Inventing Ireland (1995), Irish Classics (2000) and Ulysses and Us (2009). 
Ireland's New Religious Movements by Olivia Cosgrove, Laurence Cox, Carmen Kuhling and Peter Mulholland (eds),

Newcastle upon Tyne: Cambridge Scholars Press, 2011, ISBN: 1-4438-2588-3. £49.99 stg. hb $423 \mathrm{pp}$.

\section{Reviewer: Eamon Maher}

The proliferation of new religious movements in Ireland was the common thread that led to a group of academics from various Irish universities coming together to organise a conference in Maynooth in 2009. The topic clearly had a wide appeal, as can be seen from a total of 44 presentations from 64 participants representing 11 countries and 15 disciplines. The proceedings, published in an attractive hardback by Cambridge Scholars Press, make for interesting reading.

The editors' Introduction, which deals with the vastly changed religious landscape in Ireland (north and south) during the past few decades, sets the scene admirably. While the Catholic Church, for centuries a hugely influential institution on the island of Ireland, has been rocked in recent decades by the clerical abuse scandals and their subsequent cover-up, the main Protestant and Jewish churches have also been affected by an ever-increasing tide of secularism and materialism. However, religions outside the established churches have continued to blossom. New religious movements are described as being closely linked to the 'New Age Movement' in the way in which they bring 'very large numbers of Irish people in contact with yoga, meditation, traditional Chinese medicine, reiki and other forms of "alternative" and/or "complementary healing"' (p.1). The editors provide the following useful distinction: 'What makes a "new religious movement" is not the absolute age of its beliefs, sacred texts or practices, but the fact that most of its members are converts, that it has little power, social status or wealth and that it faces established religions which are embedded in the fabric of society' (5-6).
Christianity itself once fell into this category during the Roman Empire. For a long time Ireland was perceived as being 'religiously monolithic', with the result that the scientific study of religions has primarily been concerned with how Protestantism and Roman Catholicism became so closely aligned with ethnicity and state allegiance. Little attention was given to the long history of religious diversity in Ireland, a lacuna the essays in this book seek to address.

The 1960s and 70s 'saw both a countercultural move towards religious innovation or the recovery of supposedly ancient beliefs and practices, and the formation of fundamentalist groups within traditional or mainstream belief systems and religious regimes' (9). Certain groups such as the Charismatic Renewal Movement got a hostile reaction from the Catholic Church, while the Moonies were accused of using brainwashing techniques: 'In 1983, a group of bishops issued a Lenten pastoral warning of the danger of "cults" and "nondenominational Christian Groups"” (13-14). Weber's theory of secularisation maintained that increased rationalisation in the wake of modernisation led to the 'disenchantment of the world' and a consequent turning away from religion. This thesis held sway from some time but is no longer viewed as adequate to capture the complexity of reasons why people who abandon formal traditional religious practice often seek new and alternative ways of reaching for the transcendent. The editors rightly note how attitudes are slow to change: 'In a world where religious fundamentalism and atheist polemic have come back with a vengeance, 
where spirituality has apparently become more privatised and individualistic, and where religious diversity is now an established fact, the social, scientific, historical and psychological study of new religious and quasi-religious groups in Ireland is definitely worth our time' (23-24).

Readers will understand how pressure of space will not allow discussion of all 18 chapters in this book. Excising a few of these chapters might have been a good idea, as there are some that are noticeably weaker than others. Malcolm Macourt makes excellent use of the 2006 Census of Population in his discussion of the impact of the 'New Irish' on the religious landscape in the south, but he also examines figures from the Northern Ireland Census of 2001. Questions posed in relation to religious allegiance and practice have to be phrased in delicate terms and this can sometimes produce somewhat skewed results. Ireland's embrace of Buddhism is the topic of chapters 3 and 4. John L. Murphy refers to Michel Houellebecq's 1998 novel, Atomized, whose main character, Michel Djerzinski, finds in the infinite architecture of cross and spiral in the Book of Kells something akin to Tibetan Buddhism's contemplation of circular forms of mandalas. At the end of the novel: 'He unlocks the molecular trigger that allows infinite copying of cells without mutation or disturbance' (94).

Attracta Brownlee's chapter on the fascination of the Irish travellers for priests with special powers and New Age healers concludes that travellers, rather than rejecting Catholic beliefs in favour of new religious movements, 'tend to reconcile and incorporate elements from the new beliefs and practices into their own belief system' (110). This seems to mirror what many Irish people do: they pick certain aspects of different belief systems and form a type of personal composite religion that covers their spiritual and psychological needs in a more satisfactory manner. Jenny Butler demonstrates that Neo-Paganism is still reasonably widespread in Ireland: "The term "Pagan" stems from the Latin word paganus meaning "country-dweller". Neo-Pagans have reclaimed this original meaning but have also added new meanings to the term' (114) The affection for traditional ritual sites has never waned in Ireland: 'The spiritual connections to place are intertwined with mythology and history and these terms continually appear in Irish Neo-Pagan discourse, artistic expression and material culture' (117). Belief in 'fairy places' and pagan gods are characteristic of this movement, whose adherents (including Druids with alleged special powers) often visit places like the Hill of Tara for the summer solstice.

Peter Mulholland's chapter on the visionary Joe Coleman's claims that he was the beneficiary of Marian apparitions is a stand-out piece. Mulholland traces the moving statues phenomenon and cites Michael Allen's assessment of the way in which these were best understood 'as an attempt by devotees to halt what they perceived as being the moral disintegration of Irish society consequent on the spread of secular values' (181). In addition, they provided a more attractive and meaningful form of devotion than that which was available in normal sites of worship. Joe Coleman grew up in a world where discipline and repression were commonplace and where negative reinforcement of sexuality and the threat of Hell's fire inspired fear and trepidation. Mulholland does a type of psychological profile of Coleman and points out that the pain of losing his father at a young age, his self-avowed altercations with the devil, a serious injury that caused him to have to give up work, his visions and healing powers, all led him naturally to espouse a certain spiritual path. Rather than dismissing Coleman's powers as mere fabrication, Mulholland argues that anyone who has the capacity to get ten thousand people to assemble in Knock for an unsuccessful Hallowe'en apparition by the Virgin Mary deserves to be taken seriously.

Carmen Kuhling observes how during the Celtic Tiger 'the Irish state became enchanted with its own disenchantment'. The abandonment of organised religions by a large number of people led to a massive paradigm shift: 'In some ways, unquestioned faith in the texts, apostles, cathedrals and rituals associated with Catholicism have simply been superseded by unquestioned faith in texts, apostles, cathedrals and rituals associated with consumption, and which are bound to the mythologies of economism and neo-liberalism' (201). In Kuhling's view, New Age Spiritualities are 
symptoms of a desire 'for re-enchantment in the context of both the crisis of the Catholic Church, and more recently the economic crisis' (201). This seems a more than reasonable thesis. She analyses the etymology of 'Celtic Tiger' with the first word conjuring up the image of a romantic, mist-covered landscape whereas the second denotes 'the rhetoric of competitive individualism' (205). In such an environment, the allure of the New Age Traveller, whose life 'takes the form of a pilgrimage, or the search for identity, truth and meaning outside the routines of our daily existence' (217), is undeniable.

You will have gathered from this brief overview that there is much of relevance in this collection. New Religious Movements are more diverse than this reader had imagined and they seem to answer a keen need in people for a different type of spirituality than that which is being currently supplied by the established churches. While the editors are to be commended for their fine work, there is nonetheless some evidence of overlap, especially in the numerous references to the disillusionment with the Catholic Church in the wake of the clerical abuse scandals or the perceived need of alternative medicine, which come up in a number of different essays. Overall, however, this is a most welcome examination of a heretofore neglected area, and it is warmly recommended to anyone with an interest in the spiritual evolution of contemporary Ireland.

Eamon Maher is Director of the National Centre for Franco-Irish Studies in IT Tallaght and editor of the Reimagining Ireland book series with Peter Lang Oxford. In 2011 his monograph 'The Church and its Spire': John McGahern and the Catholic Question was published. At present he is also co-editing two books, Peregrinations and Ruminations: FrancoIrish Connections in Space and Time (with Catherine Maignant) and Picking up the Pieces: A Socio-Cultural Critique of the Celtic Tiger (with Eugene O’Brien). 
City of Bohane by Kevin Barry

London: Jonathan Cape, 2011

ISBN 978-0224090575

288 pp. £11.99 (Paperback)

\section{Reviewer: John L. Murphy}

This picaresque tale blurs Limerick street-slang and Cork lingo into cowboy, pirate, gangster, and Celtic archetypes to unleash mayhem and murder upon a decaying Irish seaport, set in the middle of the present century. Kevin Barry's debut novel builds upon his successful short stories in There Are Little Kingdoms. The scope of Barry's uneven but boldly conceived City of Bohane, set on a fictional peninsula facing the Atlantic, enables him to channel his island's traditional lore of windswept bogs, garrulous low-lifes, and mordant humor into a place wide enough to open up his cinematic visions. Showdowns recalling Gangs of New York, Mad Max, and A Clockwork Orange contend against satirical contests indebted to Flann O’Brien, who sent up in At Swim-Two-Birds similar Western showdowns against a backdrop of goats, tramps, and shifty fellows.

Barry adds considerable amounts of violence and far more explicit vocabulary than could be given to O'Brien in a national climate once infamous for censorship. For the postapocalyptic, feral streetscapes of Bohane, where a 'lost time' has ended and something dreadful has happened that by its never being explained remains all the more menacing, street justice rules. Honor among thieves is the motto as much as the city newspaper's masthead: 'truth or vengeance'. Neither cellphones nor the internet appears. No account of what has happened worldwide is revealed. International exchange seems to have been reduced to a wine bottle or photographer's developing fluid smuggled in from Portugal. It is as if the seventeenth century has returned. An Irish port again opens up to piracy, duels, and treachery.
Logan Hartnett has long ruled the Fancy, the local crime gang. His wife, Macu, finds her loyalties challenged when an old flame, the Gant Broderick, returns to the city after a mysterious and prolonged exile overseas. Jenni Chang, all of seventeen years old in a tight catsuit, makes her own bid for power. Grudges linger and betrayals ensue. Meanwhile, police, press, and meddlers watch to see how the Fancy fares against the upstart Norries and the sand-pikeys--one from the city's projects, one a tribe from the nearby dunes - who, dressed as fops in finery, will challenge with knives, chains, and boots the reign of sartorially impeccable Logan and his Fancy squad who try to keep control of their corrupt gains.

What they control is quite altered from today's Ireland, if cleverly extrapolated from contemporary demographic and cultural trends changing the island. Calypso and dub, fado and ska dominate the sounds heard from the Norrie high-rise flats and the Smoketown slums by the river. The Big Nothin' extends north of the Norrie turf into the hinterland, where a regression to tribalism has occurred. The few affluent live in Beauvista's mansions downtown, but the images of coriander, curry, Chinese brothels, drug dens, butchers' remnants and brewery smells, tropical heat and Caribbean costume make this a multicultural city in the west of a dystopian Ireland that displays Barry's verbal and visual imagination.

'The bog was dried out and above it a shifting black gauze of midge-clouds palpitated and the turloughs had drained off and there was that strange air of peace in the hills: never-changing, sea-tanged, western. The horizon wavered in 
hard sun over the poppy fields as the workers toiled in silhouette at the crop. Bleached light on the plain of Nothin' and a fado lament wailed distant from somewhere on the pikey rez. His feet were blistered.'

This passage demonstrates the familiar setting of a bog, but altered by poppy cultivation, and desiccated to emphasize its Western qualities of a flat land far away from the North Atlantic fringe. Barry, as in his earlier stories, presents big men left to wander along a diminished island too small for their ambitions. As in his previous collection, the tales told here also mark such things as the fado, sounds of a changed Ireland.

'Who's allowin' who to live?' One character asks the question which pervades this sinister saga. It follows the familiar themes of a Sam Peckinpah revenge film or Sergio Leone spaghetti Western. Weather-beaten if welldressed hardmen line up, enemies are bought out, challengers are tricked, and callow rivals eliminated as vengeance follows the elision of truth. Criminals fill every drinking establishment and house of ill repute with their boasts, their whispers, and their regrets.

Barry chooses to tell his erratic narrative through an oddly in-the-know figure, who is rarely glimpsed, an archivist of old film reels from the 'lost time', yet how this person knows so much from all over is not explained. The adjustment necessary to enter this upended, predestined story fully, told in a formidable pastiche of Irish slang mixed with perhaps a reggae-meets-'chav' spin on what is a ghettogypsy-globalized patter - demands concentration.
As with his short stories, memorable language and restless characters remain Barry's strength, sometimes more than plot, structure, or originality.

Considerable suspension of disbelief, as in a tale of ancient adventure recounted by a bard, may suffice to move the reader along its timetested, familiar path. The partly predictable direction that this plot follows retains vigour in the style of its wry, filthy, witty, stubbornly unexplained argot. This command of jargon infuses a fresh, bitter, bracing quality into this ambitious mash-up, set in such an oddly halffamiliar, half-distorted place as Bohane, half on the Irish coast, half in a timeless Western saloon.

Prof. John L. Murphy coordinates the Humanities sequence at DeVry University's Long Beach, California campus. His Ph.D. is from UCLA in medieval English literature. Irish language reception by English-language culture, Irish republicanism, Beckett's purgatorial concepts, Jews in medieval Ireland, the reception of Buddhism by Irish intellectuals, folk-rock in Irish counterculture, and the presentation of otherworldly, liminal states in medieval and modern literature illustrate his published research. He reviews books and music over a broad range of topics in print and online, and he contributes to PopMatters and the New York Journal of Books regularly. 
Witness Trees by Lorna Shaughnessy.

Cliffs of Moher, Co Clare: Salmon Poetry, 2011.

ISBN 978-1-907056-78-9

69 pp., €12 (paperback)

\section{Reviewer: Manuela Palacios ${ }^{1}$}

Witness Trees is Lorna Shaughnessy's second book of poems after the collection Torching the Brown River (2008), also published by Salmon Poetry. Moreover, she has experience in the translation of contemporary Mexican poetry, as her books with poems by Pura López Colomé and María Baranda (both in Arlen House, 2006) attest. In fact, Shaughnessy's writing is a paragon of border-crossing, from the North to the South of Ireland, from the island to the European mainland and, across the ocean, over to the American continent. An exclusive focus on the familiar terror of a violent North might prove to be too ensnaring, so she also incorporates into her poetry the experience of those who struggle for life in the world's remotest corners.

Witness Trees is a book about surviving a traumatic past. The author provides two different sources for the title of the collection. A poetic reference, Robert Frost's "Beech", connects the Witness Tree with the need to bear witness to past wounds (25). The second source is explained in the epigraph of the title poem "The Witness Trees", where Martin Jacoby describes the characteristics of this conifer: the tree that survives the passing of a dune grows bigger, becomes more productive and its seeds inherit its remarkable performance. Shaughnessy is fascinated by the resilience of these "testigos", the umbrella pines in the Doñana Nature Reserve

1. This review has been written in the context of the research project, funded by the Spanish Ministry of Science and Innovation (FFI2009-08475/FILO) and by the Galician government (INCITE09-204127PR), for the study of contemporary Irish and Galician women writers. in south-western Spain: "They reach down into unsuspected sources / and root, stretch towards an intuited light. / As the sand rises they keep their heads above land / and remember to grow" (40). The first line break in this quotation is a perfect example of how syntax and lineation match the subject matter, as the reader becomes involved in the struggle of the tree to find a firm rooting place.

This book collection is divided into three parts: I. Rebuilding, II. Witness, and III. Survivors, a structure that unsettles the cause-effect expectations about witnessing in the first place, surviving next and, finally, rebuilding. Shaughnessy does not seem to trust such teleological orderliness. In the first part, the writer glides smoothly from human to nonhuman nature: landscapes become allegorical motifs : "but her life bore a closer resemblance to a hilltop bog" (17); humans fail in their responsibility to protect the environment: "I lug my guilt up the hill, try to shake it off / but it settles like a hump on my back" (16); the caged birds' song "though undeserved, still redeems" (18), thus unveiling the soothing powers of nature. The landscapes depicted may initially remind us of W.H. Auden's "The Watershed", a poem that lends its voice to nature only to confirm humans' alienation from it: "Go home, now, stranger" (1966: 23). However, Shaughnessy encourages us to overcome first impressions, "No snow, but a hard, hard frost" (15), and discover the beauty that lies hidden: "angular pucks of ice with rainbows inside" (15). The asceticism of the landscape matches the sober style and versification. "Rebuilding", the third poem in the collection, ends with a note of 
hope that hovers over the whole first part, as it refers to nature's obstinate hold on life: "Somewhere, robins are rebuilding unseen / with unsurpassed, invisible skill” (16).

The second part, "Witness", contains a substantial number of poems on the Northern Ireland Troubles. This is verse about trauma and taboo which, with the passage of time, gives way to the irrepressible need to raise one's voice "I've run out of reasons not to speak" (27). Geoffrey Hartman (2003: 257) claims that the task of trauma studies is to discover the "psychic wounds" in the accounts of traumatic experiences. Reading Shaughnessy's “The Harpist" (30-31) in this light, one first notices her overt references to political violence "Six bullets his body took in nineteen eighty-four / as they left the Church that ordinary Sunday, / the day his daughter died in his place. Six bullets". A more attentive reading, however, spots those psychic wounds in grief-related notions of numbness "my stunned awkwardness at the funeral", entrapment "Ambushed by the suddenness of memory", unreliability "I [...] feel the familiar scepticism rise" and ghostliness "But now, the likeness in her mother's picture / brings old grief closer, makes a fiction of the coming year".

If the four-poem series "Belfast Obituaries", placed around the centre of the collection, denounces the vicious cruelty of the Northern Ireland conflict, poems like "Exodus", "Arpilleras" and "His Mother's Apron" delve into the predicament of marginalised and oppressed groups in other lands. These are poems peopled by Central-American migrants who risk their lives as they cross the border with the United States, Chilean mothers and wives who search for their missing ones, and an Armenian painter who struggles with memories of starvation and confronts his trauma with the help of art.

The tragedy of a survivor's ordeal is that, after they manage to live through an unbearable experience, they usually find themselves alone. They have no one with whom they can verbalise their experience of suffering and turn it into a chronological narrative, which is an essential step in the recovery from trauma. The third and final part of the collection, "Survivors", begins with a series of portraits of such lonely people whose voices speak "lines from another play, another time" (49). Like the rest of the book, these are songs of experience that have not given up on hope: "Light the lamp of love with jasmine oil / to arouse my senses from sleep, // soothe away the pain of knowing / and dress me in the lustre of innocence" (55).

As the writer Mary O'Donnell says in her back cover endorsement, "Shaughnessy writes with lyric intensity and uncompromising music". The readers of Witness Trees will not fail to appreciate the courageous and honest voice that speaks through the collection. In it, there is no room for superfluous adornment but just the best-wrought poetic craft.

\section{Works Cited:}

Auden, W.H. 1966. “The Watershed”. Collected Shorter Poems. 1927-1957. London: Faber and Faber. 22-23.

Hartman, Geoffrey H. 2003. “Trauma within the Limits of Literature”. European Journal of English Studies 7.3: 257-74.

Manuela Palacios is Senior Lecturer at the University of Santiago de Compostela in Spain. She has directed two research projects on contemporary Irish and Galician women writers that have been funded by the Spanish Ministry of Science and Innovation and has co-edited several books in relation to this topic: Pluriversos (2003), Palabras extremas (2008), Writing Bonds (2009), Creation, Publishing and Criticism (2010), and To the Winds Our Sails (2010). 
Aibítir Aoise: Alphabet of an Age by Celia de Fréine

Dublin: Arlen House, 2011

ISBN 978-1-85132-027-1

104 pp., $20 €$ (hardback)

\section{Reviewer: Manuela Palacios ${ }^{1}$}

Aibítir Aoise: Alphabet of an Age is Celia de Fréine's fifth poetry collection. Her first two poetry books, Faoi Chabáistí is Ríonacha (Cló Iar-Chonnachta, 2001) and Fiacha Fola (Cló IarChonnachta, 2004) were published in Irish; her third collection Scarecrows at Newtownards (Scotus Press 2005) was written in English; her fourth and fifth poetry books, imram:odyssey (Arlen House 2010) and her latest collection here reviewed, have come out in bilingual editions with English translations by the poet herself. In fact, one could argue that these English versions are not really translations of a source Irish text and that this kind of edition challenges deeprooted notions about originals and translations. The advantage of these dual-language editions for the international dissemination of the writer's work is unquestionable. On the one hand, the Irish version gets the visibility it deserves: those of us who regrettably have no command of Irish become fascinated with the radical difference of this language, try to decipher the meanings encrypted in Gaelic and engage in the exciting adventure of learning a new code, while, on the other hand, the English version reaches a wider readership. Bilingual editions may then turn out to be a productive strategy for the survival of poetry in minoritised languages, although there remains the risk of the bear hug and some may feel apprehensive about the encroachment of English on Irish-language literature.

1. This review has been written in the context of the research project, funded by the Spanish Ministry of Science and Innovation (FFI2009-08475/FILO) and by the Galician government (INCITE09-204127PR), for the study of contemporary Irish and Galician women writers.
Celia de Fréine, a doyenne of Irish letters, is a widely awarded poet, playwright, screenwriter and librettist. If for her 2010 poem sequence imram: odyssey she sought inspiration in Imram —an Irish literary composition which recounts a voyage to another world- for Aibítir Aoise: Alphabet of an Age, she has turned to a Polish genre, the Alphabet Book, about one's life-time observations. The alphabet form also provides the structure of the collection, as the poems are set in the order of the traditional eighteen-letter Irish alphabet. This repertoire of poems has a round structure, as it begins and ends with a similar concern with writers' aspirations. Thus, the collection opens with the title poem, where the lyrical voice presents her writing project: "Answers will outlive me / only if I ransack / that pocket of time, // claw out its secrets, / sift them into letters / to fashion into words" (15). The last poem "Uaireadóir": "Watch" takes satisfaction in the achievement of this project and in its particular joust with time: "Now that I've ransacked that pocket of time, / my watch lies silent in a drawer, / the span between seed and sickle contracts. // I read over what I've done, / open the shutters / and let in the morning light” (103).

Metapoetic considerations abound in this collection. Sometimes, as in “Ár nDán Féin”: “A Fate of Our Own”, poetry is construed as a protective realm of pleasurable and playful creativity: “[...] you'll want to scurry for shelter / to the poem-house so that / we can lie on a futon of words // swap the most pithy of metaphors / 'til multifarious letters escape [...]" (31). On other occasions, the poetic voice struggles with her audience's expectations and 
with the challenge of verbalising an unspeakable past: "Who are we to bear witness / when we can do only what is asked of us?" (49). "Roghanna?": "Choices?" elaborates on the tensions between originality and intertextuality, on language as a communal construction and on our unconscious absorption of other writers' idiom: "[...] When I lift my pen to write / how much of what I say is mine and mine alone?” (91).

In line with her concern with artistic influence and collaboration, Celia de Fréine often acknowledges, in epigraphs to her poems, the work of fellow writers, artists and friends from Ireland and abroad: Caitlín Maude, Fidelma Ní Ghallchobhair, Phyl Herbert, Éilís Ní Dhuibhne, Françoise Connolly, Antonella Anedda, Biju Viswanath, Dora Boneva, Lyubomir Levchev, Josefina Plá, Shi Tao and Xohana Torres. Regarding the last two writers, de Fréine provides us with her Irish and English translations of their poems. Translation, often defined in negative terms as betrayal traduttore, traditore - and loss, becomes, in de Fréine's hand, the most apt instrument to pay homage and show complicity with a writer's work. Her Irish rendering of a poem by Shi Tao, "Meitheamh", was first written for the PEN Poem Relay to protest against the Chinese Government's imprisonment of Shi Tao. De Fréine's Irish and English recreations of "Penelope", a poem by Xohana Torres, pay tribute to one of the most influential poems in Galician literature. ${ }^{2}$ Xohana Torres' Penelope, tired of waiting for Ulysses' return, decides that she also wants to sail. Her unconventional cry

2. Xohana Torres' "Penélope" was included in her collection Tempo de ría (A Coruña: Espiral Maior, 1992). Celia de Fréine wrote one initial Irish version of this poem for the anthology To the Winds Our Sails. Irish Writers Translate Galician Poetry, edited by Mary O’Donnell and Manuela Palacios (Cliffs of Moher: Salmon Poetry, 2010, p. 59).
"TO SAIL I TOO” became a feminist vindication in the Galicia of the 1990s and signalled women's determination to fully participate in the public sphere.

Irish myth and folklore necessarily inform a number of poems in the collection, as is the case with "Derbforghail", about the Wife of Lughaidh, "one of the first immigrants to this country" (33). This poem delves into the predicament of the female foreigner, who is envied, despised and challenged by the women in her adopted community. The story unfolds in sober style, with scarce but eloquent modifiers ("your ice-hair", "your arctic pelt", "the temperate air"), with balanced stanzas and no abrupt line breaks, all together contributing to a captivating narrative flow. De Fréine's bardic stance also inspires her critique of contemporary political and economic corruption in "Huth Ná Hath": "Here Nor There", where the humorous tone adds to the subversive and irreverent outcry.

Aibítir Aoise: Alphabet of an Age succeeds in distilling the life secrets that time has masked and does so with verse that proceeds with mature poise. Past and present, legend and fact, craft and intuition inform each other effectively achieving "a balance between one order and the other" (21).

Manuela Palacios is Senior Lecturer at the University of Santiago de Compostela in Spain. She has directed two research projects on contemporary Irish and Galician women writers that have been funded by the Spanish Ministry of Science and Innovation and has co-edited several books in relation to this topic: Pluriversos (2003), Palabras extremas (2008), Writing Bonds (2009), Creation, Publishing and Criticism (2010), and To the Winds Our Sails (2010). 
A History of the Irish Novel by Derek Hand

Cambridge: Cambridge University Press, 2011, ISBN 978-0-521-85540-2

341 pp., Hardback £55.00 (\$90.00)

Reviewer: Gerry Smyth

This impressive account of the 'Irish novel' arrives at a time of crisis for both the noun and the adjective - which is to say, for both the form which is the study's subject matter, and for the national tradition in which it is located. It may seem that to say so much is to say not very much at all: every time, apparently, has been a time of crisis for the novel - whether it's the form's tentative emergence during the seventeenth and eighteenth centuries, its consolidation as the bourgeois literary form par excellence during the nineteenth century, or the destabilisation of its core constituents during the twentieth century. Despite the discourses of critical regulation and canon formulation which have shadowed its evolution, the novel has always been in a state of 'chassis', to some degree. For many commentators, indeed, such a condition accounts in large part for the novel's power and attraction as a cultural form.

The current threat to the novel represents something else again. For a year or so now, students have been turning up to my seminars with various electronic devices containing downloaded versions of the novels we are supposed to be studying. (You know the brands.) There has been a degree of disruption - for example, when trying to locate a particular passage for discussion, or when discovering that Emily or Tom have actually been social networking rather than focusing on critical issues. Resistance is useless; it's a trend that's only likely to increase (what did you get for Christmas this year?), and it seems clear that both the novel form and its attendant pedagogical practices are going to have to change radically as a consequence. No doubt people will still write and read and write about things called 'novels', but the quickening pace of the digital revolution means that everyone is struggling to understand how those practices - 'writing', 'reading', 'writing about' - will evolve in a future that's already here.

Perhaps the Irish novel is better equipped to handle the current crisis than those produced under the auspices of other national traditions. As Hand argues throughout this attractive book, the Irish novel occupies a unique position within the history of the form in so far as it traditionally operated on the margins of what was itself a marginalised discourse. Its abject cultural condition after the Glorious Revolution rendered Ireland ripe for the development of a cultural practice that was characterised by recalcitrance, partiality and fracture; the Irish novel, it turns out, was Modernist long before Joyce decided to revolutionise the form.

If 'the novel' has entered a period of significant crisis, then so too has the qualifying national identity invoked here: 'Irish'. Every month brings a fresh assault upon that misfortunate descriptor; the speed and the extent of the Republic's fall from capitalist grace have severely compromised the established languages that we have all, until recently, used to discuss matters 'Irish'. Then again, that particular word was always, like the novel, a signifier under erasure: the farmer, the stockbroker and the emigrant were all 'Irish' in some sense, but the question of both the extent and the essence of any shared identity was always strained, even before the current crises. Again, the parallel with

ISSN 1699-311X 
the novel is striking: both the national identity and the cultural form have striven for coherence and legitimacy throughout their careers; both will probably survive, but in ways and in forms that would be unrecognisable to earlier practitioners. The inference is clear: 'It's an "Irish novel”, Jim, but ...' - well, you know the rest.

In any event, and all this being so, it was an extremely judicious moment in which to produce an overview of the 'Irish novel', and anyone with an interest in contemporary Irish Studies in general, and in the Irish novel in particular, should be grateful that the task fell to someone so well equipped for the task. This is a study long in the researching and the writing, and it certainly shows. Hand's work progresses by way of a thorough familiarity with both the archive of primary sources as well as the array of critical and theoretical discourses which may be brought to bear upon those sources. (One wonders, by the way, if in the light of recent developments, Lukács - so unfashionable for so long - is due a comeback.) At the same time, it is 'a' history rather than 'the' history; no sensible academic especially one who has read Joyce as carefully as Hand - would have the temerity to offer the latter.

The book incorporates a number of 'interchapters' - a relatively novel device that I first encountered in Declan Kiberd's Inventing Ireland (1995). I don't know if the practice is now more widespread, or what precisely it's intended to achieve. In Professor Kiberd's magisterial volume the interchapter functioned as a kind of précis, separated from the 'real' book by its rendering in italics, and momentarily zooming out from the main critical narrative in order to offer an overview of the wider situation. In the study under discussion here, the individual interchapters operate rather differently, in as much as they afford the author an opportunity to show off his critical skills by providing an extended analysis of a single text that exemplifies issues explored with greater concision in the preceding chapter. These representative interchapter texts are: Virtue Rewarded; or, the Irish Princess, Castle Rackrent, The Real Charlotte, Ulysses, The Last September, Doctor Copernicus, Reading in the Dark and That They May Face the Rising Sun. There's your module on the history of the Irish novel already prepared!

This book provides an essential foundation for the study of the Irish novel from the (rough) date of its emergence (Richard Head's The English Rogue, 1665) to as close to the present as it's possible to get in this format: Julian Gough's Jude: Level I (2007). Other studies may be more focused or more nuanced. Fair enough. So far as I understand the matter, however, this text provides precisely what you want from your Academic Press Overview: a critical discourse that is accessible, informative and full of suggestions for further and future research. We await the emergence of the post-Tiger dispensation, in academia as in other walks of Irish life; in the meantime, A History of the Irish Novel should be essential reading in the field for the foreseeable future.

Gerry Smyth is a Reader in Cultural History at Liverpool John Moores University. He is the author of numerous books on Irish culture, including The Novel and the Nation (1997), Space and the Irish Cultural Imagination (2001), and Music in Irish Cultural History (2009). He is currently preparing his adaptation of The Brother for performance at the Edinburgh Fringe Festival, and completing a monograph entitled Treason and Betrayal in the Modern Irish Novel. 